\title{
Tabooed Subaltern: A Study of Ghulam Abbas' Reshma and The Women Quarter
}

\author{
Sadaf Mehmood \\ Department of English \\ International Islamic University Islamabad
}

\begin{abstract}
Woman in Pakistan is defined through her body. Throughout her life she bears the burden of family honour and prestige to move in patriarchal society of Pakistan. In such a society where women experience different socio-cultural and economic marginalization, it becomes difficult to articulate oppression of the fallen women who trade their honour and prestige for the sake of money. While challenging the sociocultural standards of honour, the sufferings of their lives are completely neglected within the confinements of hegemonic patriarchy. These socially outcast women are tabooed subaltern who experience the brutalities not as human beings but as objects and commodities. An invisible line is being drawn by the patriarchs between these fallen women and the mainstream society whereby the respectable women devoid of any socio-economic discrimination live and struggle for their survival. To investigate the intricate lives of tabooed subaltern, present study dwells on subaltern theory of Gayatri C. Spivak. This research aims to investigate that how tabooed woman exhibits her agency but remains unheard or silent and how the literary world articulate intricate existence of tabooed subaltern within socio-cultural chains? To examine this, I have selected Ghulam Abbas' Reshma and The Women's Quarter which discuss the positioning of tarnished women who are, because of their ruined celibacy, alien to the society where men and women perform their traditional roles with honour and respect. The study is significant to extend and develop Spivak's dealing of socio-cultural silence to identify how literature might form an alternative archive attuned to the complexities of voicing the tabooed subaltern.
\end{abstract}

Keywords: Subaltern, Women, Oppression, Representation.

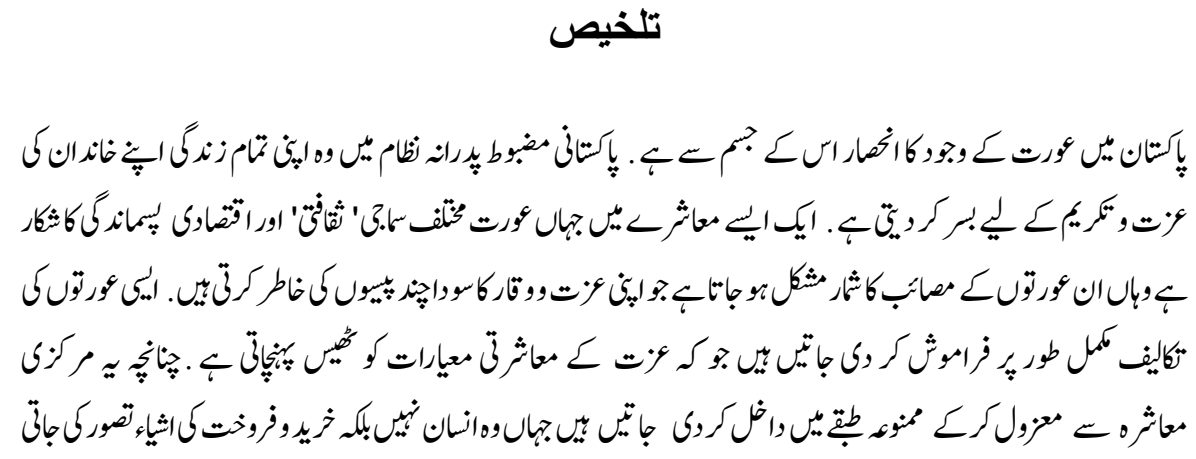




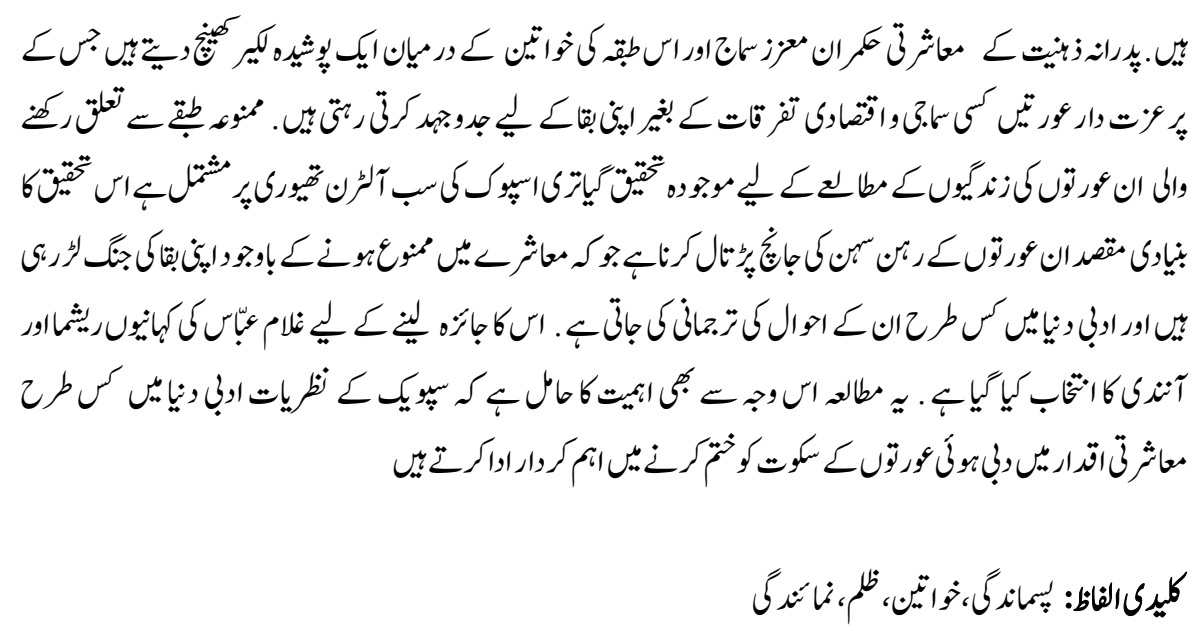

\section{Introduction}

Social positioning of Pakistani woman is reliant on her economic and geographic conditioning (Tarar, 2014). Women consist of half of the population of the country are striving for the provision of their basic rights of health and education. By supplying false religious allegations Pakistani woman is subjugated and thus oppressed in socio-cultural autonomies. In patriarchal structure of Pakistani society where male is dominant due to his economic and physical puissance, the women is obliged to be subservient within domestic sphere. While associating woman more with body her existence is confiscated for the preservation of family honour. The present day woman of Pakistan is struggling to deconstruct the patriarchal constraints. The state along with the activists' agencies is engaged to provide women equal opportunities to survive in the society. However, all the joint forces could not liberate women from the patriarchal confinements of norms and taboos yet legal interventions provide definite protection against any strong male dominant ideology. Nonetheless, to picture the legal system of Pakistan with reference to women's rights, than it is still engaged in amending and revising the legislative documents to protect women from the ills of patriarchy.

In such bitter circumstances whereby woman is grievously meeting the standards of patriarchy it seems impossible to voice troublous miseries of those women who are ensnared by the negotiations of their honour. These women are known as fallen women who manage their everyday lives on the margins of the society. These socially outcast women experience the brutalities not as human beings but as objects and commodities. An invisible line is being drawn by the hegemonic patriarchs between these fallen women and the mainstream society whereby the respectable women devoid of any socioeconomic discrimination live. 
In Pakistani society when a respected woman is unable to break the cultural codification, justice for such fallen can never be imagined. In this study, I find these fallen women as tabooed subaltern due to their exclusion from mainstream society. Encyclopedia Britannica defines taboo as 'the prohibition of an action based on the belief that such behaviour is either too sacred and consecrated or too dangerous and accursed for ordinary individuals to undertake' (Fershtman, 2011, p. 140). Diverse explanations are supplied to define taboo as a cultural and social imposition; however, alternative perspective is given by Sigmund Freud (1955) by accentuating the strong unconscious restrictions that adheres by the generations. Fauzia Saeed calls the sex industry as a taboo culture that is nurtured by the unknown mafia. The dynamics of this mafia are fully facilitated by the political agents that evidently intrude any threatening interruptions in the smooth functioning of such vile business (Saeed, 2011). Drawing over Saeed's association of word taboo I use it for fallen women as tabooed women who exist in the society but remain prohibited, unknown and definitely tabooed. These tabooed women are the subaltern because of their inability to voice their oppression and their unawareness of the agency.

The tabooed subaltern lacks socio-legal and politico-cultural protection in Pakistan against any vehemence that they experience in their lives. For analogous situations Spivak insists over the need of representation to voice such silences, to narrate the untold and unheard stories. To proceed with this my argument is framed over Gayatri Spivak's theoretical interrogations of subaltern as an oppressed and socially neglected subject that can be voiced through representation, as Beverly elaborates, through approximation. Literature as a medium of representation and approximation of reality through narration can be called as treasure trove of locating voices of subaltern. God of Small Thing (1997) by Arundhati Roy and Slum Child (2010) by Bina Shah are some prodigious instances of highlighting the socio-cultural and economically neglected class of subaltern. In Moth Smoke (2000) Mohsin Hamid scathingly delineates the intricacies of sex trade and commodification of prostitutes. Danial Mueenuddin in his collection of stories narrate a diverse and equally convoluted perspective of the lives of women associated to different social standards. Urdu literature of Pakistan provides rich thematic account of the social realities that fail to reach international audience. The short fiction of Ghulam Abbas is phenomenally sensational and moving with significant insistence on voicing the subaltern to demonstrate convoluted existence of different socially and economically deprived people. To examine his abilities of representation through approximation I have selected his stories Reshma and The Women's Quarter (Anandi in Urdu) with specific reference to trace the voices of tabooed subaltern. This research aims to investigate the intricate lives of tabooed women in such a society wherein women with certified esteem sigh for their rights. The research finally concludes that in everyday lives these tabooed women strive to dismantle their peripheral substitutes but they fail to do so. 


\section{Literature Review}

Enucleating the 'poverty' of Indian national history, Ranajit Guha (1996) renders historiography as a spurious production of elite heroism (Guha, 1996, p. 3). 'They wrote up the history of nationalism as the story of an achievement by the elite class, whether Indian or British' (Chakrabarty, 2000, p. 471). While celebrating the burlesque feint of elitist heroism, national history has failed to interpret 'the contribution made by the people on their own, that is, independently of the elite to the making and development of this nationalism' (Guha, 1996, p. 3). By exposing the meretricious veracity of history, Guha (1996) has established a new discipline; 'Subaltern Studies' to integrate the absence of common people from their national history. Drawing over Antonio Gramsci, Guha explicates the domination of elitism through his discourse on hegemony and borrows his word 'subaltern' to introduce the non-elite class that is excluded from history because it has no contribution in constructing the socio-economic institutions. For Guha (1984) history could only be enriched if the efforts of subaltern groups are acknowledged through academic revisions of history.

Intelligentsia of this newly born discipline has developed its argument by defining subaltern as an oppressed subject within the hegemonic suzerain of elitism. Gayatri Spivak (1994) in her essay Can the Subaltern Speak?, examines subaltern as an oppressed class that cannot voice its oppression owing to the hegemony of western discourse. By confining subaltern within gender and class specification, Spivak (1994) seeks subalternity as being manipulated by the politics of representation. By evaluating the limited scope of first world Feminism and contending with Deleuze and Foucault, Spivak (1994) delineates the infidelity of western discourse to address third world subaltern. Subaltern becomes invisible in the thick mist of catachresis, when the transparency of intellectuals becomes vague to demarcate representation as representation. Spivak (1994) defines subaltern subject as incapable to represent itself that instigated the western intellectuals like Foucault and Deleuze have to articulate the oppressed for which they effaced their role. However, as the moment comes to voice the disenfranchised they switched their role as intellectuals. She evaluates this shift because of their reliance over conflated representation where subaltern becomes the coherent political subject whose desire and interest are interpreted as unanimous.

Spivak castigates that subaltern as political coherent subject, "if given chance... and on the way to solidarity through alliance politics... can speak and know the conditions' while interrogating the hegemonic conditions of representation, 'can the subaltern speak?' (p. 78). By unfettering the representation mechanisms whether 'darstellen', or 'vertreten' spivak suggests that 'beyond both is where oppressed subjects speak, act and know for themselves' that however, 'leads to an essentialist, utopian politics' (1994, p. 71). Spivak (1994) perceives subaltern as incongruent and heterogeneous subject of desire and 
interest. She continues to argue that the otherness of non-western world remains mystery for West that could merely be explored by considering the indigenous elite as subaltern and for this reason episteme merely focuses over the centre (the West) and generalizes the peripheries. This generalization eventually produces homogenous subaltern devoid of any differentiation of class and gender. The produced discourse to articulate the subaltern eventually silences its voice.

In this context the 'woman is doubly in shadow' (1994, p. 84). Spivak condemns the equivocation of global sisterhood whereby the First World woman strives to speak on behalf of the Third World oppressed sisters who cannot speak for themselves (Spivak, 1981). Third-world woman experiences heterogeneous oppressions that can never be homogenized under the single slogan of global sisterhood. Spivak rejects this utopic frame of first-world feminist resistance because of the inaccessible otherness of thirdworld woman:

Between the patriarchy and imperialism, subject-constitution and object-formation, the figure of the woman disappears, not into a pristine nothingness, but into a violent shuttling which is the displaced figuration of the 'third -world women' caught between tradition and modernization (1994, p. 102).

Perceiving historiography in the parameters of stimulus-response and by critically examining the paradoxical interventions of West to define the Other, Spivak castigates the justifications for the legalizing white man's burden. The existence of third-world woman is oscillating between tradition and modernity that cannot be comprehensible for the first-world woman, however, Spivak suggests that instead of speaking for them the first-world woman can 'learn from them' and 'speak to them', the discourse of homogeneity could be deconstructed (Spivak, 1981, p. 156). The critique of epistemic violence of western discourse does not aim to evaluate the legal premises of civilizing mission, Spivak enunciates that how the homogenous versions of freedom have been represented whereby 'the constitution of the female subject in life is the place of differend' (1994, p. 97). Spivak analyses the tragedy of Bhuvaneswari Bhaduri; a woman who had participated in freedom movement was a symbol of modern woman in the third-world. To conserve her dignity, she preferred self immolation in context of Satti practice over her appearance before British colonizers as a convict. Her agency was revealed when she immolated herself during her menstruation against the ethics of Satti ritual. However, her immolation was misrepresented by her own family as an outcome of an illicit love. Hence, Bhuvaneswari could not voice her devotion and those who could, have re-presented her as an immoral woman. Spivak's polemical conclusion elaborates that the 'subaltern as female cannot be heard or read' due to the equivocal re-presentation. The silence of woman in the course of representation directs Spivak to emphasize over the need of indigenous representatives owing to the shared socio-cultural context. She categorizes the 
regional dominant groups who could potentially voice the subaltern, nonetheless, the subaltern that is the unconscious of her oppression is only acknowledged by her dominant master as oppressed.

The subaltern cannot speak. There is no virtue in global laundary lists with 'woman' as a pious item. Representation has not withered away. The female intellectual as intellectual has a circumscribed task which she must not disown with a flourish (1994, p. 104).

Bart Moore-Gilbert (1997) discerns Spivak's trajectory of female subaltern as 'doubly marginalized by virtue of relative economic disadvantage and gender subordination' (1997, p. 80). Gender subordination extends the definition of female subaltern who is experiencing oppression within the premises of class and gender with further elaboration of caste, religion and the domestic norms. Moore-Gilbert agrees with Spivak for explaining female as doubly oppressed by further explicating the possible lines of repression, however, he identifies several incongruities lurking in her argument as she 'asserts that the subaltern cannot speak, she is, of course, herself constituting and speaking for, or in place of, the subaltern' (Moore-Gilbert, 2005, p. 464). He continues to argue that if it has been impossible subaltern to be represented as Spivak has suggested, then no text has been produced about them.

The purpose of writing Can the Subaltern Speak?, states Spivak was to public the tragedy of Bhuvaneswari Bhaduri, however, it is evident that while voicing the subaltern like Rani of Sirmur, Bhuvaneswari, she is also inveigles elitism by articulating the middle and upper-class women. The strategic violations of representation and repressions are even yet oblique. Spivak maintains that these two women 'will be instructive if they remain singular and secretive' (1990, p. 245). Their silence is epitomized through their tragic absence from the historical discourse (Spivak, 1999, p. 244). John Beverley (1999) congruently renders Spivak's politics of representation to allow subaltern to 'speak for itself' (Beverley, 1999, p. 39). He identifies the possibilities of silencing the subaltern within the ken of academic purview projections, for this reason, he does not make any assertions of representing the subaltern "we do not claim to represent ('cognitively map", "let speak", "speak for", "excavate") the subaltern' (Beverley, 1999, p. 40). However, meantime, in his pretext for studying the subaltern he asserts:

We can approximate in our work, personal relations, and political practice closer and closer to the world of the subaltern, but we can never actually merge with it. We were to go to the people' (Beverley, 1999, p.40).

Beverley defines the question of representation of subaltern by using the word approximation whereby subaltern though in reality cannot voice however it does register the approximation of its repression. 
Subaltern studies registers rather how the knowledge we construct and impart as academics is structured by the absence, difficulty, or impossibility of representation of the subaltern. This is to recognize, however, the fundamental inadequacy of that knowledge and of the institutions that contain it, and therefore the need for a radical change in the direction of a more democratic and non-hierarchical social order (Beverley, 1999, p. 40).

For Beverley the gaps within the academic discipline of subaltern are one of the factors that define its significance because they call for: 'a radical change in the direction of a more democratic and non-hierarchical social order' (Beverley, 1999, p. 40). These underlying factors at the same time also generate the possibilities of social change. At this stage Beverley concurs that subaltern should be voiced through representation whether it is cathectic approximation. This would make the subaltern knowable if not heard.

Spivak's theorization of subalternity can be perceived as a more comprehensive insight to women's positioning within national and cultural boundaries instead of the preposition of universal subjugation. The present study elaborates subaltern agency and its consequent silence through the politics of representation; however, this representation is an approximation that articulates female subaltern who cannot speak for herself. Spivak's theorization of subalternity as oppressed and silent due to the hegemonic constraints of socio-cultural and religio-political connotations explicates South Asian woman as doubly in shadow. With reference to this, the current study is delighted to examine the subaltern woman of Pakistan who bears her existence in the suzerain of patriarchy with all its connected nomenclature whereby her representation is appropriated that reveals subaltern as known but remains unheard.

The parochial society of Pakistan has legalized the patriarchal obligations whereby woman is encumbered with ponderous jargons of honour and dignity. The lexicon of good vs. bad has encaged women within selected confinements. She celebrates her legal liberties by defining herself as independent emancipated women but her character depends upon the patriarchal prescriptions that bound her to obedience and subjugation. Within such an entrenched milieu, the lives of those who do not conform to the societal codification of honour sob in periphery. The scale of status measurement of woman categorizes them below 'bad' instead a 'taboo' subject. While alienating these fallen women as taboo the men have unfettered themselves from abundant interrogations. Qayyum et al. (2013) probes commercialization of sex into two kinds of exploitation voluntary and involuntary exploitation. Voluntarily engagement in sex trade includes women who get start as prostitute willingly because of poverty, hunger, economic crisis, family pressure, illness etc.' whereas involuntarily confines 'women who enter in sex 
industry by force like trafficking, coercion, kidnapping and being deceived' (Qayyum, et al., 2013, p. 399). Both categories indicate diversity of oppressions and suppressions in mainstream society that lead women to its peripheries. Qayyum investigates the intensity of misery that these fallen women experience while living on the margins of society whereby the pimp and the customers treat her as their property who unfortunately does not voice her vehement oppression due to the absence of any socio-legal support.

By exposing the hidden realities of Red Light Area in Pakistan, Fouzia Saeed (2011) delineates that these tabooed women have been besmirched, disrespected and outcast by the men of the society. She realizes the sensitivity of her study through constant intrusions of the government officials to obstruct her survey. Fouzia Saeed (2011) narrates the tragic falls of the women of the brothel who could not breathe into the free air and ask for justice against those who have violated their rights. The laws are made and amended for the protection of women however no significant law has been made to protect those hapless women who have been dragged to the gate of immorality and disrespect by certain active mafia whether through abduction, kidnapping, trafficking or rape. If once they dismally experience the abhorrence they could not trace their way back to their loved ones and live their lives as fallen women (Sidhwa, 1989). These fate smitten women could not voice their tragedies and if they do they remain unheard. The only solution as Rehman (2011) traces out, to honour them in the society is to marry them however, the respectable men do not consider this as a practical solution that eventually bury them deep into the vile quagmire of atrocities (2011, p. xiii).

Ghulam Abbas who devoted his pen to Urdu literature, has done marvels in short fiction. Due to the dearth of translated version, his prodigious collection remains unknown to international audience. Abbas' rumination for the underprivileged excogitates his readers. The derelicts sob and articulate their forlorn days and nights within occluded confinements of socio-economic measurements. In The Women's Quarter and Reshma, Ghulam Abbas narrates the despondent lives of tabooed subaltern who are struggling to claim their right in the society but their efforts go in vein. Through his acute approximation Abbas precociously ponders over the precarious existence of notorious women which eventually reveals that subaltern can be voiced but remain unheard.

\section{Research Methodology}

This research is a qualitative and analytical study in which close textual analysis of Ghulam Abbas' The Women's Quarter and Reshma, is carried out in order to articulate the miseries of Tabooed Subaltern. The theoretical work of Gayatri Spivak and the selected short fiction of Ghulam Abbas are the primary sources of data collection. The secondary sources, however, provides affluent scholarly insights through books of criticism, journal articles and reviews on theorization of subaltern subject. This paper aims to interrogate the following research questions: 
1. How tabooed woman exhibits her agency but remains unheard and silent?

2. How literary representations articulate the intricate existence of tabooed woman within socio-cultural chains?

\title{
Silences of the Tabooed Subaltern
}

The Women's Quarter is a story that discusses the positioning of tarnished women who are, because of their delinquency, alien to the society where men and women perform their traditional roles with honour and respect. The story begins with a meeting of city council where all respectable gentlemen are gathered to discuss the expulsion of women's quarter; the brothel. The agenda of the meeting engages each individual to express their opinion for the eviction of the inhabitants of this quarter who labour their bodies 'for an evenings's entertainment' and are, for this reason, 'considered by the city fathers as an outrage against humanity, civilization and public morality' (Abbas, 2000, p. 40). Nomenclature of morality and civilization associates women to specific gendered roles whereby she is glouriously adored for her docility, conformity, innocence and devotion. The respected gentlemen are afraid of abasement of their conduct and therefore decide their execution from the centre of the city:

These women reside in an area which is not only the centre of town but also the hub of trade and commerce. All of us have to walk through this quarter. Our women, our wives, mothers and daughters, have to visit this area....it is only natural that when our women look at these shameless, half-clad street walkers and notice how they have beutified themselves, they should be led astray and feel tempted to model themselves after these creatures.' (Abbas, 2000, p. 40)

\begin{abstract}
Abbas criticizes the redundant thinking patterns of the men of the society who consider women merely as an object of beauty with debilitating moral conduct who could be seduced by these creatures. Presence of these women with their ruined celibacy could mislead the respected community to futile engagements. They assume that their involvement in beautifying themselves could 'ruin a happy home and destroy its peace' (Abbas, 2000, p. 41). Under the aegis of the discourse of honour, the women of Pakistan is domesticated and further marginalized in the absence of this preservation. The protection of women's honour echoes the family and the manly honour. The presence of this quarter amidst the city epitomizes 'shamelessness, lack of manliness, cowardice, aggressiveness, theft and forgery' (Abbas, 2000, p. 41). Encumbered with the frail logics of honour, these patriarchs have associated every prevailing evil of the society to the existence of this quarter by expressing their intolerance towards them: 'the presence of this class in our midst is a matter of shame for our city, our civilization and our culture' (Abbas, 2000, p. 41).
\end{abstract}


The embarrassment that this quarter casts for the respected men inflicts them on every passing day. The question of their survival afterwards instills each individual present in the meeting hall. Abbas investigates the possibility of giving honour to these women by tying them in wedlock, however; 'for the sake of family honour and the protection of their good name, no respectable family will ever permit these women to enter their home' (Abbas, 2000, p. 43). In Pakistani society wherein women are killed for the preservation of family honour this subaltern class of fallen women could not conform their code of conduct according to the prescriptions of social morality. Abbas ponders over the bigotry of men who do not consider these women as human beings and desire their expulsion: 'The question before us is the expulsion of these women from city limits. Whether they go to hell or elsewhere, after they are ejected, should be none of our concern' (Abbas, 2000, p. 43).

The verdict of displacement of these women to the outskirts of city reveals the strength of the man power. The men of the respected families have got succeeded in liberating themselves from unseen burden of unethical practices in the society. These fallen women have been shaken over the sudden orders of displacement to a desolated place outside the city. These women have attempted to resist against the decision but they have been silenced by the officials and in the end they have to evacuate. Abbas unravels the shallow deceit of the men while narrating the episode of resettlement of these helpless women in the far-flung area from city. The builders and the agents begin to plan the construction site. The news of the new settlement instantaneously attracted the villagers from the ambience to settle their enterprise. The desolated construction site have gradually developed a mini-market from where the sweets, fruits, kebabs, baked bread can easily be bought: 'this area, which until only a few days ago had known nothing but the silence of the countryside, was now full of life and activity' (Abbas, 2000, p. 46). Day after day, after the settlement of women, the area attains reputation of economic prosperity and commercial prospect. In the new town the disenfranchised people have been facilitated by receiving a sum to ameliorate their socio-economic standing. A sizeable population has been agglomerated and converted this new settlement into:

...a whole city with its own railway station, town hall, law courts and jail. It has a population of 250,000 with a college, two high schools... and eight primary schools. Education is free-courtesy the city cooperation. There are as many six cinema houses and four banks, two of them representing the world's biggest financial institutions. (Abbas, 2000, p. 55)

After few years the city that has begun its journey from desolation, is now making its auspicious success stories with the name of Anandi. The women who have been executed from the old city now occupy the centre of the city, the centre of commerce and trade. The new settlement that has subjected to preservation of the disenfranchised and many underprivileged, has paved paths for many to socio-economic affluence. Abbas closes the 
story on a Anandi city council meeting that is arranged for 'the banishment of the women's quarter from the city as its residents trade their favours for money and are an outrage against humanity, civilization and public morality' (Abbas, 2000, p. 56). Abbas denounces these respectable gentlemen who gathered for the execution of the women who have made the city. He ironically demonstrates the respectable men of the society who have begun their journey as disenfranchised, are now expelling the displaced subaltern who have aided them to establish themselves. 'A most eloquent gentleman is now at the rostrum. "I fail to comprehend the reasons that prompted the city to permit this impure class to settle in our midst..." (Abbas, 2000, p. 56). The impurity of this class is overlooked when they have also been disenfranchised nevertheless, the convention of social morality have ingrained as their socio-economic positioning has been ameliorated.

The closing reveals Abbas' criticism over the men of the society who hegemonizes the nomenclature of honour when they all are fed by these women. By highlighting the potential of tabooed subaltern, Abbas closely inspects their agency by rebuilding their space in the society of honour and dignity; however, their subsequent displacement from the city pictures brutal configurations of hegemonic dominance. By voicing few men from the meeting hall Abbas presents the manipulating discrimination of the so-called social ethics. In The Women's Quarter from displacement to resettlement and then again the displacement Abbas' women characters remain silent but by narrating the ongoing activities in the ambience of women's quarter and in the course of resettlement, Abbas has incarnated the misery and vulnerability of this class who could not raise voice for the sake of their survival. Thus, it is evident that the speech of male characters is exposing their hideous atrocity but the silence of the tabooed women supplies their savvy competence, who while whimpering in the social peripheries, can establish a trade and commercial centre.

In Reshma Abbas presents a microscopic insight to the lives of these tabooed women. Reshma who has been abducted in her childhood usually marries to an old, rich and respectable man of the society and pretends as his devoted wife to rob the wealth of his home. Through this promiscuous practice she supplies good amount to her clan. The versatile narrative technique of Abbas concisely decodes the ferocious life span of Reshma whose abduction has dislocated her in her own society. Abbas displays the vulnerability of women who are relentlessly suffering for no fault of their own. The violence she bears inside or outside the domestic sphere is due to her frail physical existence. The social allegations over her physical existence have imprisoned her in the congested cocoons swarming with bristling uncertainties. Fate-smitten Reshma who one after another abduction and trafficking, has been bought and sold as a lucrative source for fiscal prosperity of others. 


\begin{abstract}
Abbas previews the agonized life of women who are bound in patriarchal constraints by assigning Reshma dual role; a character of a devoted wife gratifying the ethics of honour, and a character of a treacherous woman who marries to acquire the riches of her in contract husband by deconstructing the normality of honour nomenclature. In her both roles, Abbas perceives the shrinking world for woman wherein she is not only liable for the ordeals of her committed crimes but also for others' crimes. The insight into the horrible years she has spent in the house of Karam Din is an impending reality of a conventional character of women within the domestic sphere: 'Karam Din's household, where she had earlier been, was very different. There she was treated like a slave' (Abbas, 2000, p. 126). Brutal treatment of Reshma by Karam Din reveals lurking insecurities to Pakistani women who receive no respect even after meeting the standards of good women. Reshma who remains busy in domestic chores whole day, her engrossment does not conserve her positioning in Karam Din's home. He often beats her and treats her as an object of his physical gratification that reveals his insensitivity towards woman. Karam Din epitomizes callous rituals of patriarchal men who possess women as their property by defining them as a symbol of sexuality. He is a man who measures women through her degree of servitude, obedience and devotion. Karam Din who is unaware about the obnoxious tragedy of Reshma's past treats her ruthlessly, however, as soon her reality has been disclosed he fanatically chases her to strangle her throat.
\end{abstract}

In her teens she has been sold to a mad young man who habitually beats her. A man with whom 'despite his money, no father was prepared to have his daughter marry him' (ibid). Abbas manifests Reshma as a miserable woman who survives in the socio-economic peripheries of the society who does not own any relationship in the society. Reshma has faced the challenges of her life all alone when she was only five years old. Vulnerably, she with her shadow encounters the bitter moralities of a patriarchal society whereby women oscillate between the thin dialectic of good and bad. Abbas articulates the misery and suffering of women like Reshma who dwell into the vicious muddle of isolation and marginalization from where they cannot be rescued to live a prestigious life. Abbas in Reshma has supplied diversity in the types of patriarchal agents who celebrate their power of dominance by marginalizing and silencing the women. There are two kinds of men usually exist to establish a congruent patriarchal infrastructure, men like Karam Din, and men like Chaudhri Gulab. While becoming the wife of Chaudhri Gulab, Reshma displays her fears for her new experience:

On the first day she was very nervous. She wasn't sure what she was getting herself into. She didn't know what kind of a man she had here. Was he cruel like Karam Din? Would he make her work too hard? Would he beat her up? Who would be keeping an eye on her? (Abbas, 2000, p. 125) 
Her fears erode after a couple of days when she lives her days like a mistress in his home. Chaudhri Gulab appears to be very 'simple, quiet and harmless man', an abstemious man who prays regularly (Abbas, 2000, p. 125). These attributes cannot be regarded as part of his blemish personality instead he is 'big and strong and in full possession of his physical faculties' (ibid). As a subject of oppression and misery of men, Reshma has been looking for a home where she could not experience the harshness of her life. Chaudhri's home has provided her the comfort that she has been looking after her abduction when she was just five years old. While stretching out on the cot Reshma often recalls the days she has spent in Karam Din house to feel the level of solace she is bestowed in Chaudhri's house:

Karam Din's household, where she had earlier been, was very different.

There she was treated like a slave and here she was the mistress of the place. There she had reached a point where she felt no respect for herself and hee she was treated with deference by everyone, including Chaudhri himself. (Abbas, 2000, p. 126)

Reshma's misery is revealed when Mai Jummi; the trafficker, visits her to remind her vicious purcuits at home though she declares that 'I am very comfortable in this home. I do not want to move yet' (Abbas, 2000, p. 128). Her desire to live with Chaudhri indicates Reshma's propinquity for a normal life where she could also neutralize her life under the aegis of honour and respectability. This propensity urges her to beseech Mai Jummi by offering the ornaments: " "please let me stay. Take every ornament I am wearing, and whatever Chaudhri gives to me from now on, will also be yours just let me stay" (ibid). The charisma of normal social life and sour experiences of her past romanticize the idea of good woman living inside the four walls. Her lurking propensity reveals through her attack on Mai Jummi after knowing her threatening intensions. This act of violence defines Reshma between the lines of resistance and resilience, voice and silence. However, her potential to succor her dreams instantaneously vanishes as she realizes the depth of the matter: 'Dark circles had appeared under her eyes and her face was pale as if she had been assailed by a vicious disease' (Abbas, 2000, p. 130).

The vicious disease that has ensnared her, symbolically demonstrates the turning point for Reshma. This disease shakes Reshma to break the spell of her adoration for the normal social conduct. Arrival of Karam Din brings forth Reshma out of charismatic world and she hears Chaudhri Gulab calling her, 'Wretch, shameless woman!' (Abbas, 2000, p. 131). Reshma, who prepares herself to collide with the upcoming impediments, finds Chaudhri wearing the same lens through which woman is abhorred for her ruined celibacy and adored for her cocooned passivity:

This was the first time he had spoken to her so harshly and it was strange but she did not feel hurt. In fact, she experiences a faint sense of enjoyment and the suggestion of a smile appeared on her face..... Reshma felt no anxiety or fear any longer. She had freed herself of self- 
imposed inhibitions knit around such things as morals, self-respect and right conduct. (ibid)

Throughout in her life Reshma strives to infix her feeble existence into fully edified socio-cultural set-up. She reveres the days she spent with Chaudhri Gulab as his wife, however, she strangely notices Chaudhri and Karam Din different sides of same coin. The whoremongering Reshma flees away to save her life from 'a strange couple with their white beards' but unfortunately she is caught up. Sarcastically Mai Jummi appears dramatically to rescue Reshma from them and offers them their abducted wealth. The two patriarchs and Mai-Jummi make negotiations to determine horrendous future of Reshma who silently observes the decision-makers of her fate. Her debilitating vulnerability is gnawing herself when Mai-Jummi successfully convinced the two old men to send back the anemic beauty to vicious quagmire:

Reshma was walking in the moonlight as if in a trance. She hadn't heard a word of what had been said. There was a dreamy look in her eyes. She wasn't even conscious of walking, nor aware of where she was going (Abbas, 2000, p. 135).

\section{Conclusions}

It might be noted that the selected stories define misery as collective experience for women living on the margins. Abbas' acuteness for articulating miseries of tabooed subaltern through approximation, delineates his strong narrative abilities to break the legalized silences. Abbas presents viciousness of patriarchal society whereby these fallen women could not retain respect and dignity if tragically they fell into the vile quagmire of sex industry. Present study has scrutinized that the fallen women are prohibited to be known in and sympathized by the mainstream society due to its hegemonic infrastructure of patriarchy. It is also being found that through literary representations of the tabooed subaltern an attempt is made to highlight the intricacies of their existence. While documenting the initial settlements of city's commercialization in The Women's Quarter and through Chaudhary Gulab's angst for unusual dark circles around Reshma's eyes in Reshma, Abbas presents a class of women that can be placed and then displaced and even vanquished through socio-legal allegations of honour. Through appropriation of such prohibited social realities, Abbas manifests socio-cultural and legal injustices that fallen women experience while living on the margins. The ruined celibacy of these tabooed subalterns causes eternal outcast that deprive them from any claim of being humans. This study concludes that these subalterns strive to voice their oppressions through resistance, however, this resistance is scattered that according to Spivak would remain ineffective if it is not symbiotically consolidated. In the backdrop of this study, I would recommend that the intelligentsia through media and literature should give voice to the troubles of these fallen women who are tragically collided with this mafia. I would also recommend 
that the government should facilitate the research oriented studies to disclose the afflictions of these tabooed women. Moreover, laws should be made to protect these women from sexual violence and safeguard those women who want to live a respectable life but due to social constraints they remain silent and continue their lives in brothels.

\section{References}

Abbas, G. (2000). The Women's Quarter and Other Stories from Pakistan. (K. Hassan, Trans.) Islamabad: Alhamra.

Beverley, J. (1999). Subalternity and Representation: Arguments in Cultural Theory. London: Duke University Press.

Chaim Fershtman, U. G. (2011). Taboos and Identity: Considering the Unthinkable. American Economic Journal: Microeconomics, pp.139-164.

Chakrabarty, D. (2000). A Small History of Subalter Studies. In H. S. Ray (Ed.), A Companion to Postcolonial Studies (pp. 467-485). Oxford: Blackwell.

Day, S. (2007). On the Game: Women and Sex Work. London: Pluto Press.

Frederick, J. (2000). Fallen Angels: The Sex Workers of South Asia. New Delhi: Luster Press.

Freud, S. (1955). Totem and Taboo: Some Points of Agreement between the Mental Lives of Savages and Neurotics. (J. Strachey, Ed.) The Standard Edition of the Complete Psychological Works of Sigmund Frued, vol.13, pp.1-225.

G., L. D. (Ed.). (1996). The Spivak Reader. New York: Routledge.

Guha, R. (1996). Subalter Studies I: Writing South Asian History and Society. Delhi: Oxford University Press.

Guha, R. (1984). Subaltern Studies III: Writings on Indian History and Society. Delhi: Oxford University Press.

Harry, B. \&. (1964). Prostitution and Morality. New York: The Julian Press.

Lerner, G. (1996). The Creation of Patrairchy. New York, Oxford: Oxford University Press. 
Manto, S. H. (2013 (1966)). Ismat Faroshi (Prostitution). (M. U. Memon, Ed.) The Annual of Urdu Studies, vol.28, pp.325-334.

Moore-Gilbert, B. (1997). Postcolonial Theory: Contexts, Practices, Politics. London: Verso.

Moore-Gilbert, B. (2005). Spivak and Bhabha. In S. R. Henry Schwarz (Ed.), A Companion to Postcolonial Studies (pp. 451-466). Oxford: Blackwell Publishing.

Narang, G. C. (1973). Major Trends in the Urdu Short Story. Indian Literature, pp.113-132.

Needham, A. D. (2005). The Small voice of History in Arundhati Roy's The God of Small Things. Interventions, pp.369-391.

Penttinen, E. (2008). Globalization, Prostitution and Sex-Trafficking; Corporeal Politics. London: Routledge.

Prakash, G. (1994). Subaltern Studies as Postcolonial Criticism. The American Historical Review, pp.1475-1490.

Qayyum, Shahid, et al. (2013). Causes and Decision of Women's Involvement into Prostitution and its Consequences in Punjab, Pakistan. Social Sciences and Humanities, pp.398-411.

Rehman, I. A. (2011). Foreword. In F. Saeed, Taboo! The Hidden Culture of a Red Light Area (pp. vii-xvi). New York: Oxford Unviersity Press.

Saeed, F. (2006). Good Women, Bad Women: Prostitution in Pakistan. In G. G. Westmarland (Ed.), International Approaches to Prostitution: Law and Policy in Europe and Asia (pp. 141-164). Bristol: Policy Press.

Saeed, F. (2011). Taboo! The Hidden Culture of a Red Light Area. New York: Oxford.

Sidhwa, B. (1989). Ice Candy Man. New Delhi: Penguin Books.

Spivak, G. (1990). Gayatri Spivak on the Politics of the Subaltern' (in an interview with Howard Winant). Socialist Review, vol.3, pp.81—97.

Spivak, G. C. (1999). A Critique of Postcolonial Reason: Toward a History of the Vanishing Present. London: Harvard University Press. 
Spivak, G. C. (1987). A Literary Representation of the Subaltern: A Woman's Text From the Third World. In Other Worlds: Essays in Cultural Politics, pp.241-301.

Spivak, G. C. (1994). Can the Subaltern Speak. In P. W. Chrisman (Ed.), Colonial Discourse and Post-colonial Theory: A Reader (pp. 66-111). New York: Columbia University Press.

Spivak, G. C. (1981). French Feminism in an International Frame. Feminist Readings: French Texts/American Contexts, pp.154-184.

Spivak, G. C. (1985). The Rani of Sirmur: An Essay in Reading the Archives. History and Theory, pp.247-272.

Spivak, G. (1999). Subaltern Studies: Deconstructing Historiography. In A. Elliott (Ed.), Contemporary Social Theory (pp. 244-255). New York: Blackwell Reader.

Tarar, M.G. \& Pulla, V. (2014). Patriarchy, Gender Violence and Poverty amongst Pakistani Women: A Social Work Inquiry. International Journal of Social Work and Human Services Practice, pp.56-63.

Sadaf Mehmood is Research Associate in the Department of English, Faculty of Language \& Literature, International Islamic University, Islamabad. 